Article

\title{
Impact of Social and Economic Development on Sediment Load of the Yellow River
}

\author{
Guangming Tan ${ }^{1}$, Shasha Han ${ }^{2,3}{ }^{1}$, Yuecong Yu ${ }^{4}$, Rui Hu ${ }^{5}$, Yiwei $\mathrm{Lv}^{1}$ and Caiwen Shu ${ }^{1, *}$ \\ 1 State Key Laboratory of Water Resources and Hydropower Engineering Science, Wuhan University, \\ Wuhan 430072, China; tangm@vip.163.com (G.T.); yiweiLv_whu@outlook.com (Y.L.) \\ 2 Key Laboratory of Lower Yellow River Channel and Estuary Regulation, Ministry of Water Resources, \\ Yellow River Institute of Hydraulic Research, Zhengzhou 450003, China; sshan9202@whu.edu.cn \\ 3 State Key Laboratory of Hydroscience and Engineering, Tsinghua University, Beijing 100084, China \\ 4 Power China Hebei Electric Power Engineering Co., Ltd., Shijiazhuang 450031, China; yuyc@hbed.com.cn \\ 5 Ministry of Emergency Management of the People's Republic of China, Beijing 100054, China; \\ hur@chinasafety.gov.cn \\ * Correspondence: cwshu@whu.edu.cn; Tel.: +86-135-5438-7151
}

Citation: Tan, G.; Han, S.; Yu, Y.; Hu, R.; Lv, Y.; Shu, C. Impact of Social and Economic Development on Sediment Load of the Yellow River. Sustainability 2021, 13, 7976. https://doi.org/10.3390/su13147976

Academic Editors: Maria João

Simas Guerreiro and Eunice M. Maia de Andrade

Received: 13 May 2021

Accepted: 15 July 2021

Published: 16 July 2021

Publisher's Note: MDPI stays neutral with regard to jurisdictional claims in published maps and institutional affiliations.

Copyright: (c) 2021 by the authors. Licensee MDPI, Basel, Switzerland. This article is an open access article distributed under the terms and conditions of the Creative Commons Attribution (CC BY) license (https:/ / creativecommons.org/licenses/by/ $4.0 /)$.

\begin{abstract}
Approximately $90 \%$ of the sediment yield of the Yellow River is derived from the Loess Plateau. In this paper, the Loess Plateau was used as the research object. To investigate the influence of economic and social development on reducing sediment load of the Yellow River, a mathematical method was employed with hydrological and sediment data from three hydrological stations (Toudaoguai and Sanmenxia at the Yellow River, and Ganguyi at the Yan River) as well as per capita GDP data from the Yan River basin. The results showed that the reduction in runoff in the reaches between the Toudaoguai and Sanmenxia stations accounted for $39.3 \%$ of the decrease in the sediment load of the Yellow River, and the other $60.7 \%$ of the decrease may have resulted from economic and social development. Using the Yan River basin as an example, there was an inverse relationship between per capita GDP and sediment delivery during the period from 1984 to 2018. Grey relational analysis revealed a relatively high relation between the sediment load of the Yan River and the number of rural laborers transferred from the area, the afforestation area, and the tertiary industry value of Yan'an city. Thus, economic development and social transformation are highly related to sediment delivery in the basin, which may result in a decrease in sediment delivery to some extent.
\end{abstract}

Keywords: sediment yield; economic development; social transformation; GDP; Yellow River; Yan River

\section{Introduction}

Since ancient times, the survival and development of human beings have been closely related to rivers; even now, most of the big cities in the world are still located along rivers [1]. The interactions between river systems and social and economic development of the human world are quite complicated [2]. In recent decades, as social and economic development and human activities have intensified, their impacts on river systems have become more and more obvious [3-6]. Previous studies have revealed that human activities, such as the construction of water conservancy facilities and land-use changes, have led to great changes in the underlying surface conditions of the river basins, altering runoff and sediment processes dramatically [7-9]. In particular, a significant decline in sediment load has been observed in many large river systems [10-14]. This produces problems, such as delta retreat and nutrient input reduction to aquatic and riparian ecosystems $[15,16]$, which has become a focus of attention worldwide [17,18]. Therefore, to maintain the management of the water basin sustainably, it is necessary to evaluate the impacts of different socioeconomic indicators on river sediment load.

The Yellow River is the second largest river in China and has once the most sediment transport worldwide. For example, the average annual sediment load at the Sanmenxia 
station (the controlled watershed area of which accounts for $91.5 \%$ of the Yellow River basin area) was approximately 1.52 billion tons per year between 1919 to 1953 [19]. In recent decades, with the improvement of social and economic activities, the area of the Yellow River basin has been transformed from great development to ecological protection. Various soil and water conservation measures and policies for returning farmland to forests have been adopted by the government in China [18,20]. As a result of these measures, sediment load in the Yellow River has been reduced drastically [21]. Numerous investigations of the causes of the sediment load reduction of the Yellow River have been conducted, but most of the current studies mainly focus on changes in water and sediment regime and soil and water conservation. The social and economic factors have received much less attention [2].

Social and economic conditions affect sediment load by controlling human activities [2]. For example, through socioeconomic development, an increase in government investment in returning farmland to forests, and improvements of systems of soil and water conservation, resulting in land-use changes, the sediment yield in the basin has declined [22]. In this paper, based on water and sediment data at the Toudaoguai and Sanmenxia stations and precipitation data, the causes of the runoff and sediment reduction of the Yellow River were investigated. Moreover, to discuss the influence of economic and social development on reducing the sediment load of the Yellow River, a typical tributary of the Yellow River-the Yan River basin-was selected as an example. We collected and analyzed eighteen indicators of social and economic development in the Yan River basin, and clarified relations between socioeconomic indicators and sediment load. It should be noticed that the society in China transformed from a planned economy to a socialist market economy in the period from 1984 to 2003, and individual labor was the main role of farmers during this time. After 2004, the development of the socialist market economy system matured, and Chinese society essentially became an industrial society. Thus, this paper compares the sediment load of the Yellow River between the agricultural society period (1958-1983) and the industrial society period (2004-2018) to investigate the impact of economic and social development on the sediment load of the Yellow River.

One of the outcomes of this work is an ability to better understand how economic development and social transformation affect river sediment load, so as to provide references for the sustainable development of the river basin.

\section{Regional Setting}

The Yellow River flows through nine provinces (districts) into the Bohai Sea in Kenli County, Shandong Province. The basin area is $795,000 \mathrm{~km}^{2}$, and the total length of the river is $5464 \mathrm{~km}$. The Yellow River basin is located at $32-42^{\circ} \mathrm{N}$ and $96-119^{\circ} \mathrm{E}$. Three terraces are distributed from west to east based on changes in altitude. The Loess Plateau is located in the middle part, with an altitude between 1000 and $2000 \mathrm{~m}$.

The water and sediment regimes of the Yellow River show obvious regional differences. Most of the water discharge comes from the channel reach located upstream of Lanzhou, and most of the sediment load comes from the channel reach located between Toudaoguan and Longmen as the river flows through the Loess Plateau. Figure 1 shows the area that contributes a large amount of course sediment. Due to the heavy sediment load and riverbank constraints, the lower Yellow River has high sediment deposits and is well known as a suspended river.

The Loess Plateau mainly had gullies instead of vegetation before 1983, while the soil was highly erodible. The precipitation is low, with one or two strong storms generally occurring in spring or autumn. The Yan River is a typical distributary of the Yellow River, which is located on the Loess Plateau and mainly belongs to the Yan'an administrative region (Figure 1). The area of the Yan River drainage basin is $7725 \mathrm{~km}^{2}$, which contributes approximately 1\% of the total drainage area of the Yellow River. Before 1983, Chinese society had a planned economy, in which approximately $90 \%$ of the population in the Yan River drainage basin were farmers, and rural collective labor was their main job. The 
average per capita GDP in Yan'an was 351 yuan/person (54 \$US/person), and the society was a typical agricultural society.

During the summer of 1983, researchers spent a month performing observations in the Yan River basin. From this research we know that crops there were grown on the hillslope at 20 degrees. After storms the surface of the hillslopes was severely eroded, and high sediment-laden flow was created at the tributary.

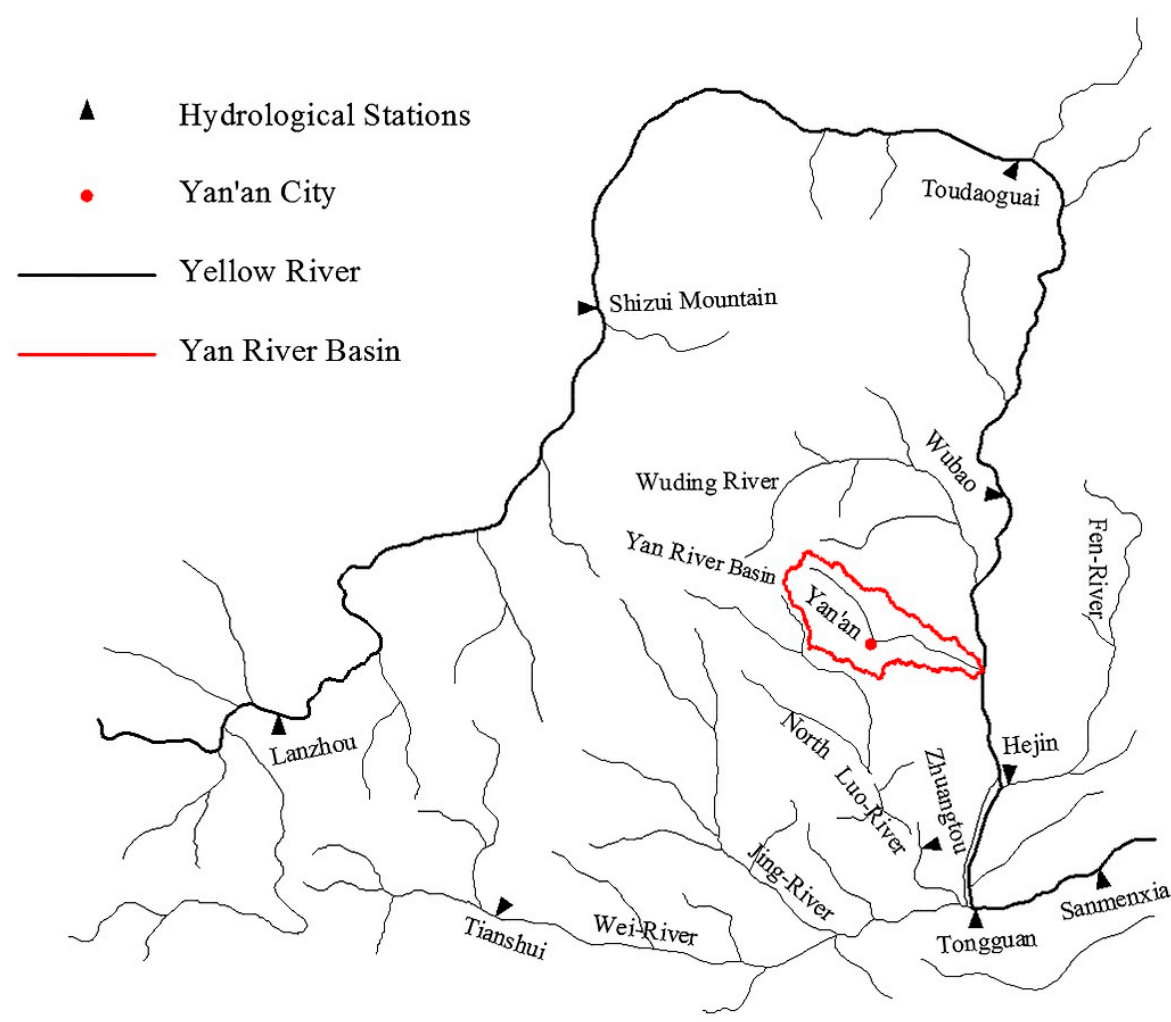

Figure 1. Drainage area of the Yellow River.

\section{Data and Methods}

\subsection{Data}

Annual runoff and sediment load data at stations of Toudaoguai, Sanmenxia, and Ganguyi (1958-2018), and annual precipitation and water consumption between the Toudaoguai and Sanmenxia stations, were provided by the Yellow River Conservancy Commission. Eighteen indicators of social and economic development in the Yan River basin, including GDP and per capita GDP; primary, secondary, and tertiary industry value; urban and rural per capita disposable income; resident population; urbanization rate; rural labor transfer; regional, industrial, and agricultural irrigation water consumption; cultivated land area, afforestation area, controlled soil and water loss area; and precipitation and maximum single-day rainfall were collected from the Yan'an and Shannxi statistical yearbooks (http: / / fzbz.yanan.gov.cn/, http:/ / dfz.shaanxi.gov.cn/ accessed on 16 June 2021). The timings of various indicator measurements were not completely consistent due to incomplete statistics in the early period of study. Indicators were generally collected from 2000 to 2018, except for the urbanization rate and the number of rural labor transfers, which were collected from 2010 to 2018 and from 2006 to 2018, respectively.

\subsection{Methods}

A mathematical method called a linear-regression analysis was employed with hydrological and sediment data from three hydrological stations (Toudaoguai and Sanmenxia at the Yellow River, and Ganguyi at the Yan River), as well as per capita GDP data from the 
Yan River basin. Linear-regression is a model to establish a linear correlation between two sets of data, so as to predict values of one set from another [23].

Additionally, grey relation analysis (GRA) was used to investigate the relevancies between water and sediment regime and eighteen socioeconomic indicators in the Yan River basin. The GRA calls upon Deng's grey system theory [24], which is a multi-factor statistical analysis method for determining the correlation grade between factors [25]. In this study, the four steps of calculation are the same as in the study of Li et al. [26]. We classified the eighteen indicators of social and economic development in the Yan River basin into three types: economic, social, and eco-environment, according to their characteristics.

\section{Results}

\subsection{Changes in Runoff of the Yellow River and Its Causes}

A decreasing trend in runoff at Sanmenxia station during 1958-2018 can be observed in Figure 2. As shown, the average annual runoff decreased $41.5 \%$, from $408.3 \times 10^{8} \mathrm{~m}^{3} / \mathrm{yr}$ during 1958-1983 to $238.7 \times 10^{8} \mathrm{~m}^{3} / \mathrm{yr}$ during 2004-2018.

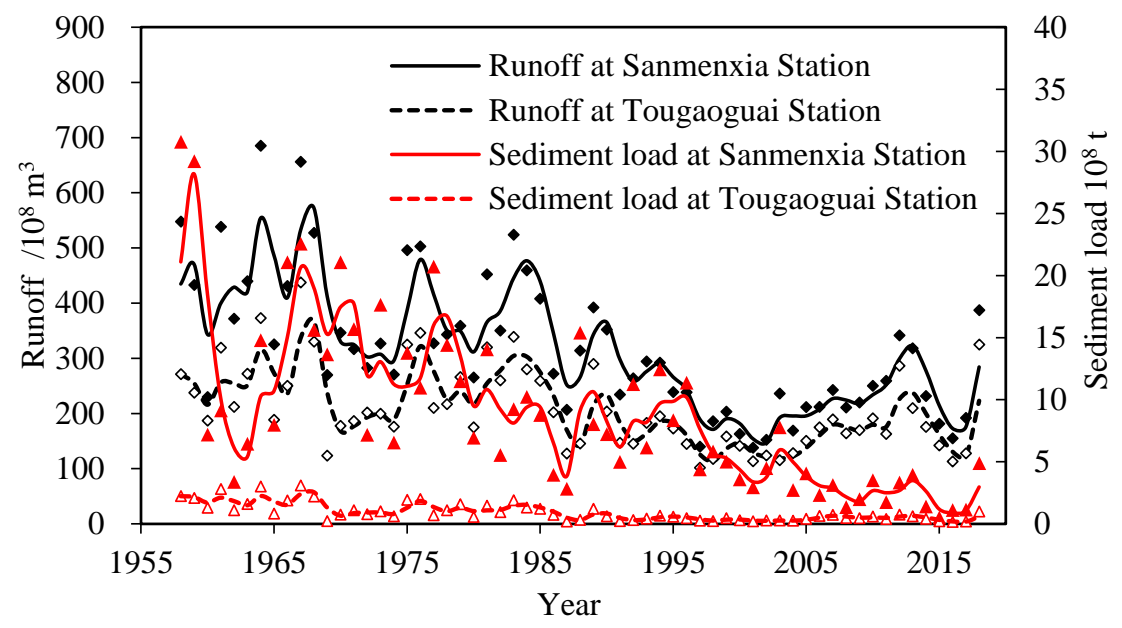

Figure 2. Annual variations in the flow and sediment regime at Sanmenxia and Toudaoguai station of the Yellow River from 1958 to 2018.

Taking the Toudaoguai station as the entrance control station, the reasons for the decrease in runoff in reaches of the Yellow River between the Toudaoguai and Sanmenxia stations (hereafter referred to as the Tou-San reach) were analyzed. The average annual runoff at the Toudaoguai station decreased by $67.7 \%$, from $253.9 \times 10^{8} \mathrm{~m}^{3} / \mathrm{yr}$ during 1958-1983 to $180.7 \times 10^{8} \mathrm{~m}^{3} /$ yr during 2004-2018. At the Sanmenxia station, the average annual runoff decreased by $82.0 \%$. The reduction in runoff at Sanmenxia station was larger than that at the Toudaoguai station, implying that the decrease in runoff at the Sanmenxia station was not only due to the decrease in runoff at the entrance control station. There were other contributing factors, such as changes in precipitation or water consumption in the Tou-San reach.

As shown in Figure 3, the average annual precipitation during the two periods of 1958-1983 and 2004-2018 was generally the same, with values of $520.0 \mathrm{~mm} / \mathrm{yr}$ and $518.1 \mathrm{~mm} / \mathrm{yr}$, respectively. However, the average annual runoff during 1958-1983 and 2004-2018 had large differences, with values of $154.4 \times 10^{8} \mathrm{~m}^{3} / \mathrm{yr}$ and $58.1 \times 10^{8} \mathrm{~m}^{3} / \mathrm{yr}$, respectively.

Taking into account the values from 1958-1983, in which the annual runoff was $154.7 \times 10^{8} \mathrm{~m}^{3} / \mathrm{yr}$ and the average annual precipitation was $520.0 \mathrm{~mm} / \mathrm{yr}$, we can assume that if conditions were to have remained the same the corresponding runoff values for 2004-2018 should be $153.6 \times 10^{8} \mathrm{~m}^{3} / \mathrm{yr}$, as the average annual precipitation was $518.1 \mathrm{~mm} / \mathrm{yr}$. However, the actual reduction in runoff from 1958-1983 to 2004-2018 was 
$96.3 \times 10^{8} \mathrm{~m}^{3} / \mathrm{yr}$. Thus, the decrease in precipitation explained only $1.2 \%$ of the runoff decrease, while other factors contributed $98.8 \%$ of the decrease in runoff.

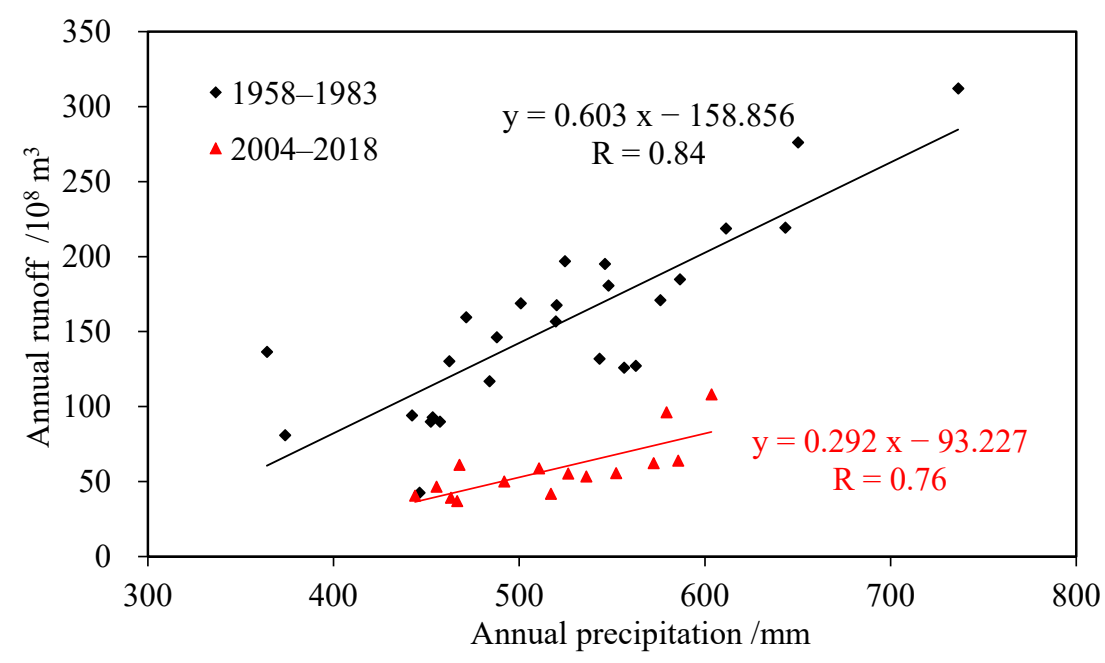

Figure 3. Relationship between precipitation and runoff in the Yellow River basin between the Toudaoguai and Sanmenxia stations.

Water consumption in the Yellow River basin between the Toudaoguai and Sanmenxia stations obviously increased (Figure 4). The average annual consumption increased from $37.09 \times 10^{8} \mathrm{~m}^{3} / \mathrm{yr}$ during $1958-1983$ to $54.24 \times 10^{8} \mathrm{~m}^{3} / \mathrm{yr}$ during 2004-2018. The relationship between water consumption and runoff in the Yellow River basin between the Toudaoguai and Sanmenxia stations is shown in Figure 5, and nonlinear regression was performed during the two periods. Even though the fitting precision was low, using the same method above for runoff reduction analysis, we estimated that increased water consumption resulted in a $54.3 \%$ decrease in the runoff. Therefore, the increase in water consumption may be the main factor affecting runoff reduction in the Yellow River basin between the Toudaoguai and Sanmenxia stations.

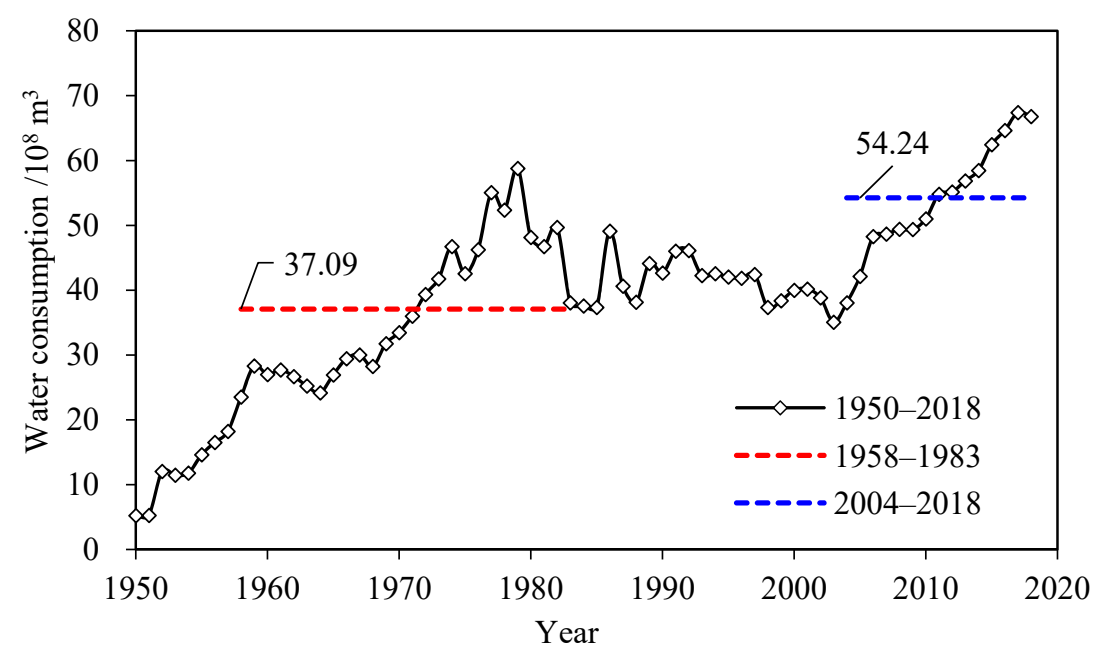

Figure 4. Water consumption in the Yellow River basin between the Toudaoguai and Sanmenxia stations. 


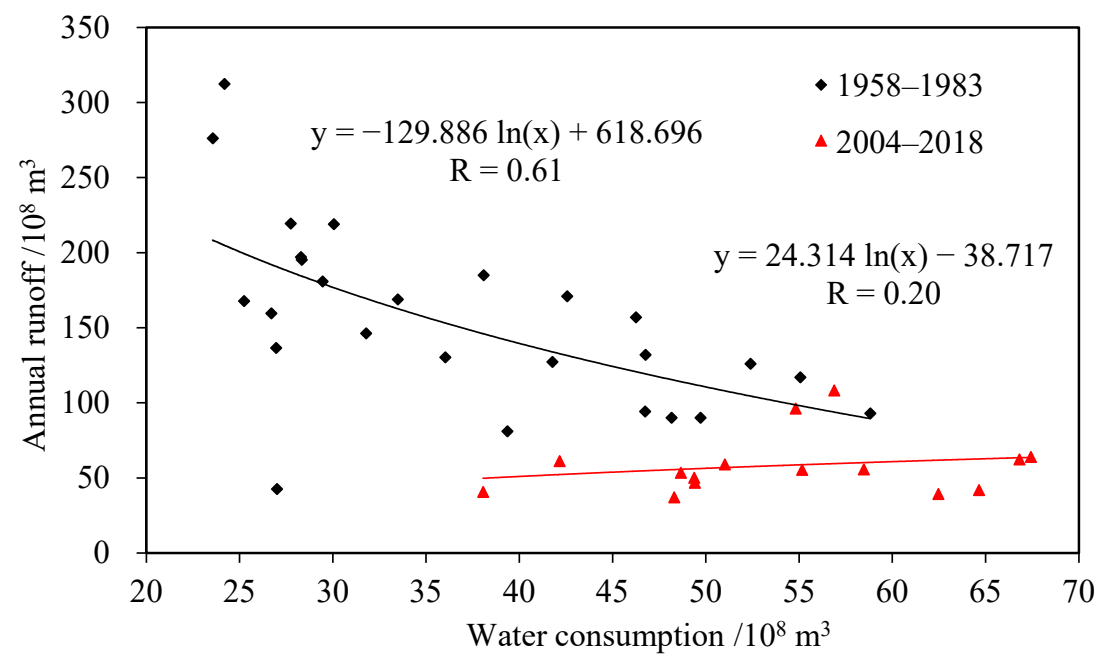

Figure 5. Relationship between water consumption and runoff in the Yellow River basin between the Toudaoguai and Sanmenxia stations.

\subsection{Changes in Sediment Load of the Yellow River and Its Causes}

There is also an obvious reduction trend in sediment load at the Sanmenxia station during 1958-2018. The average annual sediment load decreased $82.0 \%$, from $13.73 \times 10^{8} \mathrm{t} / \mathrm{yr}$ in the period of 1958-1983 to $2.48 \times 10^{8} \mathrm{t} / \mathrm{yr}$ in the period of 2004-2018. The reduction in sediment load was greater than that of runoff (54.3\%).

The reduction in runoff will weaken the flow dynamics of sediment transport. Relationship between annual runoff and sediment transport can be seen in Figure 6. Using the same method estimated that the reduction in runoff explained $39.3 \%$ of the decrease in sediment load, implying that $60.7 \%$ of the decrease in sediment load resulted from other factors.

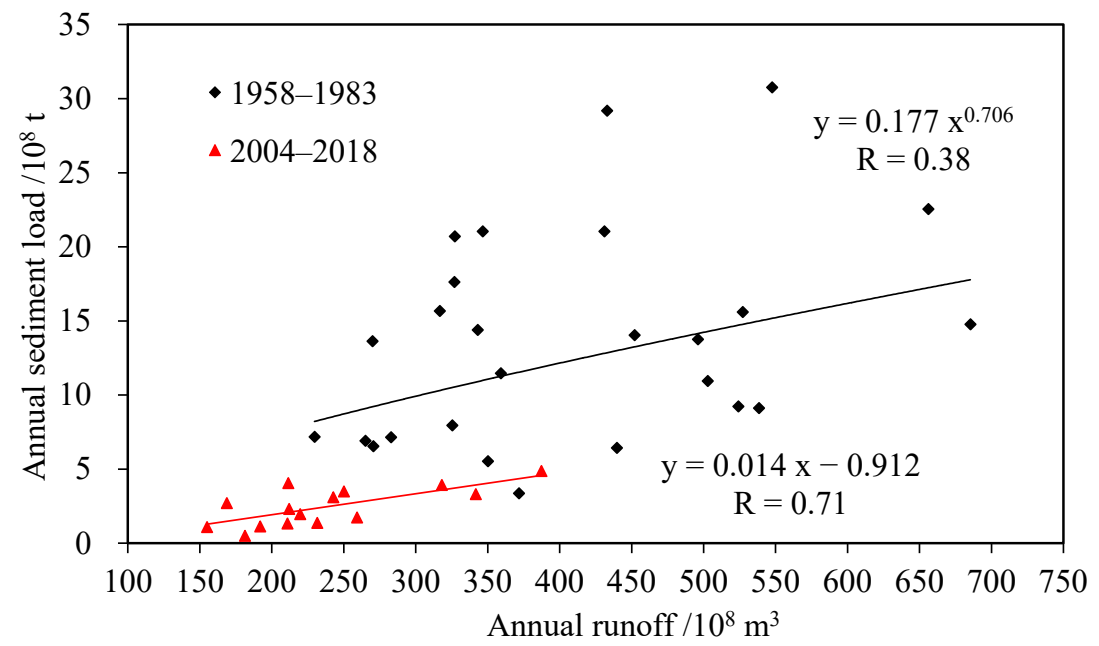

Figure 6. Relationship between annual runoff and sediment transport at the Sanmenxia station during two periods: 1958-1983 and 2004-2018.

\subsection{Relationship Between per Capita GDP and Sediment Load in the Yan River Basin}

Locating at the Loess Plateau, the Yan River basin is one of the main sedimentproducing areas, which belongs to Yan'an City (Figure 1). As shown in Table 1, the annual average sediment load of the Yan River basin accounted for $3.71 \%$ and $2.82 \%$ of the total sediment transport in the Yellow River in 1958-1983 and 2004-2018, respectively. However, the average annual runoff of the Yan River basin was only $0.55 \%$ and $0.61 \%$ of the total runoff in the Yellow River, respectively. As an important tributary of the Yellow River, the Yan River basin accounts for only 1\% of the Yellow River basin area. Hence, an analysis of 
the water and sediment changes in the Yan River is essential for the investigation of the reduced sediment in the Yellow River.

Table 1. The runoff and sediment transport proportions.

\begin{tabular}{ccccccc}
\hline \multirow{2}{*}{ Period } & \multicolumn{2}{c}{ Ganguyi Station in the Yan River } & \multicolumn{2}{c}{ Sanmenxia Station in the Yellow River } & \multicolumn{2}{c}{ Proportion } \\
\cline { 2 - 7 } & $\begin{array}{c}\text { Runoff } \\
\mathbf{1 0}^{\mathbf{8}} \mathbf{~ m}^{\mathbf{3}} / \mathbf{y r}\end{array}$ & $\begin{array}{c}\text { Sediment Load } \\
\mathbf{1 0}^{\mathbf{8}} \mathbf{t} / \mathbf{y r}\end{array}$ & $\begin{array}{c}\text { Runoff } \\
\mathbf{1 0}^{\mathbf{8}} \mathbf{~ m}^{\mathbf{3}} / \mathbf{y r}\end{array}$ & $\begin{array}{c}\text { Sediment Load } \\
\mathbf{1 0} \mathbf{~} \mathbf{t} / \mathbf{y r}\end{array}$ & $\begin{array}{c}\text { Runoff } \\
\mathbf{\%}\end{array}$ & $\begin{array}{c}\text { Sediment Load } \\
\mathbf{\%}\end{array}$ \\
\hline $1958-1983$ & 2.25 & 0.51 & 408.3 & 13.73 & 0.55 & 3.71 \\
$2004-2018$ & 1.45 & 0.07 & 238.7 & 2.48 & 0.61 & 2.82 \\
\hline
\end{tabular}

Similar to the Yellow River, the runoff and sediment load in the Yan River were reduced, decreasing by $35.6 \%$ and $86.3 \%$, respectively. The average runoff and sediment load values were $2.25 \times 10^{8} \mathrm{~m}^{3} / \mathrm{yr}$ and $0.51 \times 10^{8} \mathrm{t} / \mathrm{yr}$ during $1958-1983$ and $1.45 \times 10^{8} \mathrm{~m}^{3} / \mathrm{yr}$ and $0.07 \times 10^{8} \mathrm{t} / \mathrm{yr}$ during 2004-2018, respectively (Table 1). The average annual precipitation increased by $3.9 \%$, from $532.5 \mathrm{~mm} / \mathrm{yr}$ in $1958-1983$ to $554.0 \mathrm{~mm} / \mathrm{yr}$ in 2004-2018 in the Yan River basin. The average annual precipitation increased, while the annual runoff declined, indicating that the decrease in runoff in the Yan River basin may be mainly due to the socioeconomic development-induced increase in water consumption. The relationship between the indicator of social and economic development-the per capita GDP and the sediment load at the control hydrological station in the Yan River basin was established, as displayed in Figure 7, an inverse relationship could be observed over the past 25 years. As shown, the sediment load decreased while the per capita GDP increased, and the sediment reduction was notable early on, declining steadily to a relatively low level by the end of the period.

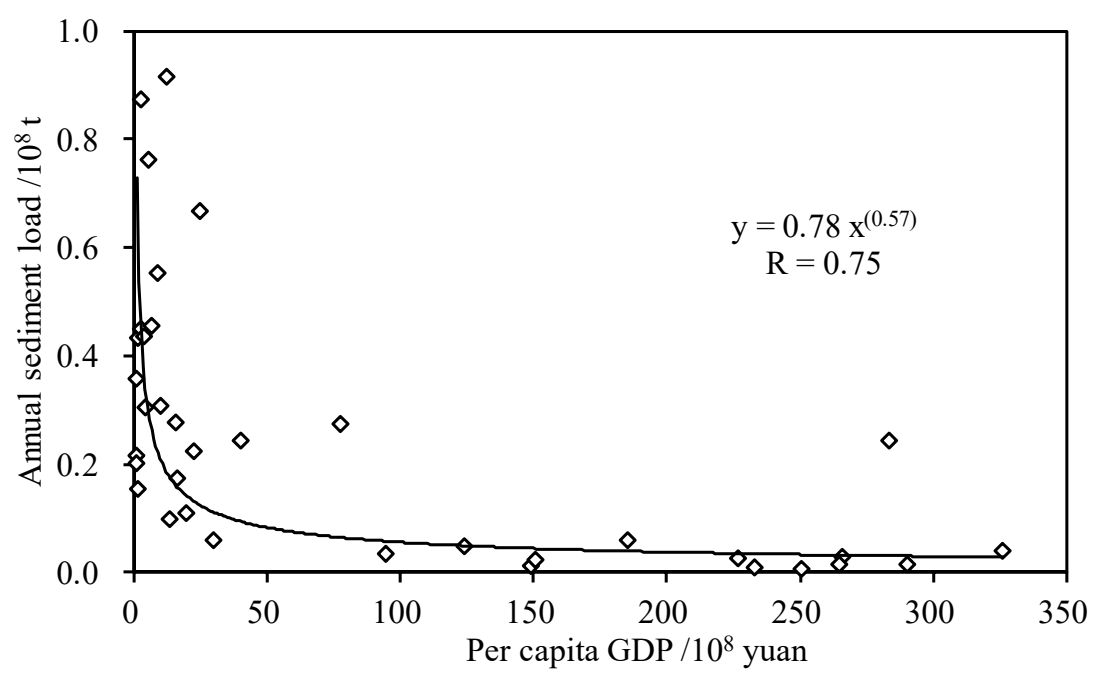

Figure 7. Curve of per capita GDP and sediment transport in the Yan River basin from 1984 to 2018.

\subsection{Analysis of Causes of Changes in Water and Sediment Regimes in the Yan River Basin}

The relationships between the water and sediment regime of the Yan River and these eighteen indicators (Figure 8) were calculated using the grey relational analysis model, as shown in Table 2. The results showed that the relationships between runoff and ecoenvironmental indicators are high, ranging from 0.650 to 0.739 . Relatively high values were observed between runoff and social indicators, with values from $0.448-0.707$. The relevancies between runoff and economic indicators were generally at the same level, with an average value of 0.586 . The relevancies between sediment load and economic and eco-environmental indicators had no significant difference, with ranges of 0.529-0.610 and 0.509-0.629, respectively. Except for the relevance between the sediment load and 
the number of rural laborers transferred, which was 0.732 , the relevancies between the sediment load and other social indicators were generally low, ranging from 0.405 to 0.535 .

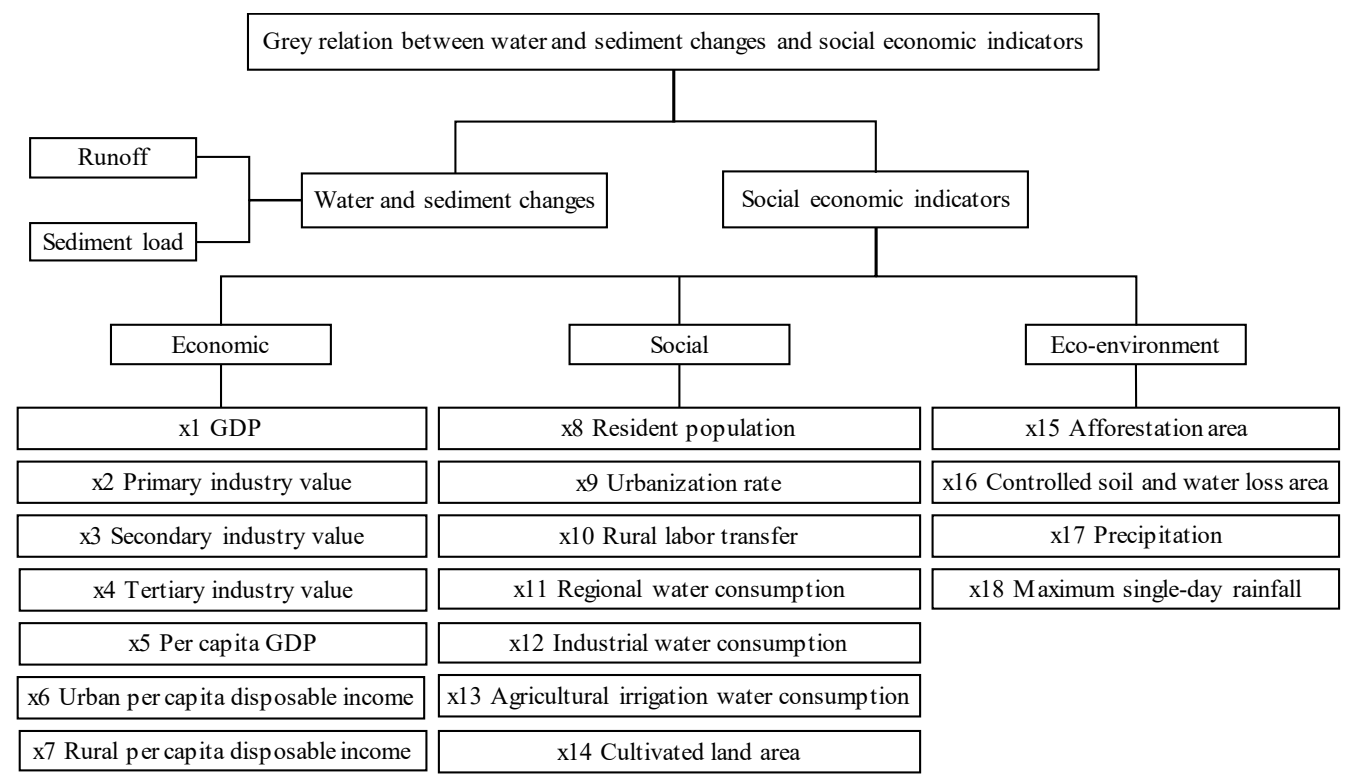

Figure 8. Grey relational diagram between water and sediment changes and socioeconomic indicators.

Table 2. Relevancies between water and sediment regime and socioeconomic indicators in the Yan River basin.

\begin{tabular}{cccccccc}
\hline Economic & $\mathbf{x 1}$ & $\mathbf{x 2}$ & $\mathbf{x 3}$ & $\mathbf{x 4}$ & $\mathbf{x 5}$ & $\mathbf{x 6}$ & $\mathbf{x 7}$ \\
\hline Runoff & 0.584 & 0.585 & 0.576 & 0.591 & 0.588 & 0.581 & 0.595 \\
Sediment load & 0.546 & 0.581 & 0.529 & 0.610 & 0.541 & 0.558 & 0.574 \\
\hline Social & $\mathbf{x 8}$ & $\mathbf{x 9}$ & $\mathbf{x 1 0}$ & $\mathbf{x 1 1}$ & $\mathbf{x 1 2}$ & $\mathbf{x 1 3}$ & $\mathbf{x 1 4}$ \\
\hline Runoff & 0.448 & 0.610 & 0.707 & 0.522 & 0.560 & 0.500 & 0.451 \\
Sediment load & 0.405 & 0.535 & 0.723 & 0.447 & 0.501 & 0.443 & 0.413 \\
\hline Eco-Environment & $\mathbf{x 1 5}$ & $\mathbf{x 1 6}$ & $\mathbf{x 1 7}$ & $\mathbf{x 1 8}$ & & & \\
\hline Runoff & 0.739 & 0.728 & 0.650 & 0.704 & & & \\
Sediment load & 0.629 & 0.566 & 0.509 & 0.550 & & & \\
\hline
\end{tabular}

\section{Discussion}

\subsection{Social and Economic Factors Affecting Sediment Yield of the Yellow River}

As shown in the analysis above, $39.3 \%$ of the decrease in sediment load resulted from the decrease in the runoff. The other $60.7 \%$ has been considered, by many Chinese scholars, to be the main effect of water and soil conservation $[9,10,12,20]$. For example, during the second half of the 20th century, high-intensity and high-standard water and soil conservation treatments were carried out in the mid-western Oklahoma basin. The sediment load of the main tributaries was reduced from $760 \mathrm{mg} / \mathrm{km}^{2}$ before the treatment (1943-1948) to $108 \mathrm{mg} / \mathrm{km}^{2}$ after the treatment (2004-2007), and this reduction was mainly caused by water and soil conservation and land-use management [27].

Soil erosion control of the Loess Plateau began in the 1950s, and water and soil conservation began to change from disorderly management to comprehensive management and planning in the 1960s. At the end of the 1970s, it was proposed that soil and water loss control should focus on sandy and coarse sand-producing areas. However, the amount of sediment reduction was limited due to the hysteresis effect of the water and soil conservation measures. The average annual sediment discharge of the Sanmenxia station in the period from 1958 to 1983 was $13.73 \times 10^{8} \mathrm{t} / \mathrm{yr}$, which was less than the value of $15.32 \times 10^{8} \mathrm{t} / \mathrm{yr}$ in 1924-1953. At the beginning of the 1980s, a comprehensive management 
strategy began, with small watersheds as units, in which water conservation measures played a significant role. By the end of 2002, a technical system for the construction of the ditch dam system with "the tributaries as the skeleton, the small watershed as the unit, the backbone dams and the small and medium silt dams matched" was formed [28-30]. Therefore, the average annual sediment discharge of the Sanmenxia station in the Yellow River decreased to $7.25 \times 10^{8} \mathrm{t} / \mathrm{yr}$ in 1984-2003.

After 1997, the central and local governments of the Loess Plateau carried out the conversion of cropland to forest, ecological construction and ecological restoration projects, and paid subsidies to farmers for forest conservation [20,31]. These measures played an important role in curbing sediment erosion and reducing sediment sources. For example, the land-use patterns in the Wuding River basin and Yan River basin changed significantly by 2013 . Sloped farmland has mostly been restored to natural conditions, vegetation is in a recovery stage, and there are a small number of terrace fields that cultivate greenhouse vegetables. In 2013, the agricultural acreage was less than one-third that of 30 years ago. Chinese society was a typical industrial society after 2004, and the per capita GDP of the Yan River basin in 2018 was 68,940 yuan/person (10,641 \$US/person), which was 196 times the levels seen in 1983. Due to the relatively low level of agricultural production, most of the rural labor force have been actively transferred to cities and are engaged in local construction, the service industry, or the oil and coal industry. The structure of rural energy consumption is also changing, previously relying mainly on firewood but now mostly using electricity, coal, natural gas, and methane. It can be said that the farmers helped with the spontaneous closure of the forest and the restoration of vegetation. These changes, e.g., the transfer of the rural labor force and changes in the structure of rural energy consumption, enhance water and soil conservation. Therefore, compared to 1958-1983, the average annual sediment load at the Ganguyi station in the Yan River decreased by 86.3\% during 2004-2018.

In summary, the reduction in runoff was mainly due to increasing water consumption and socioeconomic development. Over the past 35 years, regarding the development of the national and local social economies, the government has invested in water and soil conservation projects and subsidized farmers to increase the intensity of closing hillsides and increasing afforestation. The transfer of the rural labor force and the change in the structure of rural energy consumption were also related to economic development and social transformation. Thus, the reduction of sediment load may be highly related to socioeconomic development. To establish the quantitative relationship between the indicators of social and economic development, the per capita GDP was chosen as a characteristic quantity, and a typical tributary of the Yellow River was selected as an example as discussed below.

\subsection{The Impact of Social and Economic Development on Sediment Load in a Typical Tributary of the Yellow River}

The rapid social and economic development of districts along the river was based on the natural resources of the Yellow River. In turn, social and economic development inevitably had a certain impact on the water and sediment regimes of the Yellow River.

Taking the Yan River basin as an example, an obvious inverse relationship can be observed between sediment load and the per capita GDP over the past 25 years. This is consistent with the conclusion of Zhong et al. (2021), that socioeconomic factors in the Yan River basin promote its sustainable development [2]. More specifically, making a horizontal comparison between the relevancies of runoff and sediment load and three different categories of indicators, the results showed that the highest relevance between runoff and the three categories of indicators was 0.595 for the rural per capita disposable income, 0.707 for the number of rural laborers transferred, and 0.739 for the afforestation area. Similarly, the highest relevance between sediment load and the three categories of indicators was 0.610 for the tertiary industry value, 0.723 for the number of rural laborers transferred, and 0.629 for the afforestation area. Runoff was most related to afforestation area, while sediment load was most related to the number of rural laborers transferred. 
Similar conclusions have been drawn in precious studies [2,32-34], for example, Zhong et al. (2021) revealed that increased urbanization rates resulting from population migration led to reductions in sediment load, and cultivated land area is positively correlated with sediment load [2].

In summary, socioeconomic development has greatly affected the water and sediment regime of the Yan River. After 2000, the conversion of cultivated land to forests in Yan'an city was basically completed according to the plan. Afforestation on barren mountains and the closure of mountains for afforestation became more important factors affecting the reduction of sediment yield in the Yan River basin. The transfer of the rural labor force and the increase in tertiary industry value indicate that the improvement of people's production and lifestyle affected the changes in sediment yield to a certain extent.

\section{Conclusions}

(1). The average annual runoff and sediment load at Sanmenxia station on the Yellow River decreased by $41.5 \%$ and $82.0 \%$, respectively in 2004-2018, compared with those in 1958-1983. The decrease in runoff was mainly caused by an increase in water consumption. Approximately $39.3 \%$ of the sediment reduction was due to the decrease in runoff, and the remaining $66.4 \%$ was attributed to other factors.

(2). During the periods 1958-1983 and 2004-2018, the average annual runoff and sediment load in the Yan River decreased by $35.6 \%$ and $86.3 \%$, respectively. An inverse relation between the per capita GDP and the sediment load can be observed over the past 25 years in the Yan River basin, and the sediment reduction was notable at an early stage, steadily declining to a relatively low level by the end of the period.

(3). The sediment load in the Yan River was highly related to the transfer of rural laborers, the afforestation area, and the tertiary industry value during 2000-2018, indicating that human activities can both increase sediment and reduce sediment. Thus, in recent decades, the development of the social economy in the river basin decreased the sediment yield to some extent.

Author Contributions: Conceptualization, G.T. and C.S.; methodology, Y.Y. and R.H.; software, S.H.; validation, G.T., C.S. and Y.L.; formal analysis, S.H. and Y.L.; investigation, G.T. and R.H.; resources, S.H., Y.Y. and R.H.; data curation, S.H.; writing—original draft preparation, S.H.; writing-review and editing, S.H.; visualization, S.H.; supervision, G.T. and C.S.; project administration, G.T. and C.S.; funding acquisition, G.T., C.S. and S.H. All authors have read and agreed to the published version of the manuscript.

Funding: This work was supported by the National Key R\&D Program of China (2017YFC0405204 and 2018YFC0407800), the Science and Technology Development Fund of YRIHR (202104).

Institutional Review Board Statement: Not applicable.

Informed Consent Statement: Not applicable.

Data Availability Statement: Eighteen indicators of social and economic development used in this study were collected from the Yan'an and Shannxi statistical yearbooks (http:/ fzbz.yanan.gov.cn/, http:/ / dfz.shaanxi.gov.cn/ accessed on 15 May 2021).

Acknowledgments: We give thanks to the Yellow River Conservancy Commission for providing the data used in this study. Senior engineer Lianjun Zhao at Yellow River Institute of Hydraulic Research, Zhengzhou 450003, is thanked for giving us helpful suggestions. Comments from the editors and four anonymous reviewers are sincerely thanked.

Conflicts of Interest: The authors declare no conflict of interest.

\section{References}

1. Syvitski, J.P.; Kettner, A.J.; Overeem, I.; Hutton, E.W.; Hannon, M.T.; Brakenridge, G.R.; Day, J.; Vrocmarty, C.; Saito, Y.; Nicholls, R.J. Sinking deltas due to human activities. Nat. Geosci. 2009, 2, 681-686. [CrossRef]

2. Zhong, X.; Jiang, X.H.; Li, L.L.; Xu, J.; Xu, H.Y. The impact of socio-economic factors on sediment load: A case study of the Yanhe River Watershed. Sustainability 2020, 12, 2457. [CrossRef] 
3. Wen, T.F.; Xiong, L.H.; Jiang, C.; Hu, J.M.; Liu, Z.J. Effects of climate variability and human activities on suspended sediment load in the Ganjiang River Basin, China. J. Hydrol. Eng. 2019, 24, 05019029. [CrossRef]

4. Wei, X.; Cai, S.Q.; Ni, P.T.; Zhan, W.K. Impacts of climate change and human activities on the water discharge and sediment load of the Pearl River, southern China. Sci. Rep. 2020, 10, 16743. [CrossRef] [PubMed]

5. Wu, J.W.; Miao, C.Y.; Yang, T.T.; Duan, Q.Y.; Zhang, X.M. Modeling streamflow and sediment responses to climate change and human activities in the Yanhe River, China. Hydrol. Res. 2017, 49, 150-162. [CrossRef]

6. Guo, L.P.; Mu, X.M.; Hu, J.M.; Gao, P.; Zhang, Y.F.; Liao, K.T.; Bai, H.; Chen, X.L.; Song, Y.J.; Jin, N.; et al. Assessing impacts of climate change and human activities on streamflow and sediment discharge in the Ganjiang River Basin (1964-2013). Water 2019, 11, 1679. [CrossRef]

7. Moraes, J.M.; Pellegrino, G.Q.; Ballester, M.V.; Martinelli, L.A.; Victoria, R.L.; Krusche, A.V. Trends in hydrological parameters of a southern Brazilian watershed and its relation to human induced changes. Water Resour. Manag. 1998, 12, 295-311. [CrossRef]

8. Mu, X.M.; Zhang, X.Q.; Shao, H.B.; Gao, P.; Wang, F.; Jiao, J.Y.; Zhu, J.L. Dynamic changes of sediment discharge and the influencing factors in the Yellow River, China, for the recent 90 years. Clean Soil Air Water 2012, 40, 303-309. [CrossRef]

9. Wang, Y.; Ding, Y.J.; Ye, B.S.; Liu, F.J.; Wang, J.; Wang, J. Contributions of climate and human activities to changes in runoff of the Yellow and Yangtze rivers from 1950 to 2008. Sci. China Earth Sci. 2013, 56, 1398-1412. [CrossRef]

10. Sun, P.; Wu, Y.; Gao, J.; Yao, Y.; Zhao, F. Shifts of sediment transport regime caused by ecological restoration in the Middle Yellow River Basin. Sci. Total Environ. 2020, 698, 134261. [CrossRef]

11. Liu, J.J.; Zhou, Z.H.; Yan, Z.Q.; Gong, J.G.; Jia, Y.W.; Xu, C.Y.; Wang, H. A new approach to separating the impacts of climate change and multiple human activities on water cycle processes based on a distributed hydrological model. J. Hydrol. 2019, 578, 124096. [CrossRef]

12. Shi, P.; Zhang, Y.; Ren, Z.Q.; Yu, Y.; Li, P.; Gong, J.F. Land-use changes and check dams reducing runoff and sediment yield on the Loess Plateau of China. Sci. Total Environ. 2019, 664, 984-994. [CrossRef] [PubMed]

13. Dai, S.B.; Lu, X.X. Sediment load change in the Yangtze River (Changjiang): A review. Geomorphology 2014, 215, 60-73. [CrossRef]

14. Li, Z.W.; Xu, X.L.; Yu, B.F.; Xu, C.H.; Liu, M.X. Quantifying the impacts of climate and human activities on water and sediment discharge in a karst region of southwest China. J. Hydrol. 2016, 542, 836-849. [CrossRef]

15. Jiang, C.; Pan, S.Q.; Chen, S.L. Recent morphological changes of the Yellow River (Huanghe) submerged delta: Causes and environmental implications. Geomorphology 2017, 293, 93-107.

16. Bi, N.S.; Wang, H.J.; Yang, Z.S. Recent changes in the erosion-accretion patterns of the active Huanghe (Yellow River) delta lobe caused by human activities. Cont. Shelf Res. 2014, 90, 70-78. [CrossRef]

17. Peng, J.; Chen, S.L.; Dong, P. Temporal variation of sediment load in the Yellow River basin, China, and its impacts on the lower reaches and the river delta. Catena 2010, 83, 135-147. [CrossRef]

18. Liu, C.; Walling, D.E.; He, Y. Review: The international sediment initiative case studies of sediment problems in river basins and their management. Int. J. Sediment Res. 2018, 33, 216-219. [CrossRef]

19. Tan, G.M.; Fang, H.W.; Dey, S.; Wu, W.M. Rui-Jin Zhang's research on sediment transport. J. Hydraul. Eng. 2018, $144,02518002$. [CrossRef]

20. Deng, L.; Shangguan, Z.P.; Sweeney, S. "Grain for Green” driven land use change and carbon sequestration on the Loess Plateau, China. Sci. Rep. 2014, 4, 7039. [CrossRef] [PubMed]

21. Yu, Y.; Wang, H.; Shi, X.; Ran, X.; Cui, T. New discharge regime of the Huanghe (Yellow River): Causes and implications. Cont. Shelf Res. 2013, 69, 62-72. [CrossRef]

22. Wu, L.; Peng, M.; Liu, X. An evaluation of sediment yield evolutions for different sub-catchments and land use types in the Yanhe river watershed, Loess Plateau. Fresen. Environ. Bull. 2017, 25, 7860-7873.

23. Mozeika, A.; Sheikh, M.; Lopez, F.A.; Antenucci, F.; Coolen, A.C.C. Exact results on high-dimensional linear regression via statistical physics. Phys. Rev. E 2021, 103, 042142. [CrossRef] [PubMed]

24. Deng, J.L. Control problems of grey systems. Syst. Control Lett. 1982, 1, 288-294.

25. Winarni, S.; Indratno, S.W. Application of multi response optimization with grey relational analysis and fuzzy logic method. J. Phys. Conf. Ser. 2018, 948, 012075. [CrossRef]

26. Li, C.D.; Li, Z.B.; Yang, M.Y.; Ma, B.; Wang, B.Q. Grid-Scale Impact of Climate Change and Human Influence on Soil Erosion within East African Highlands (Kagera Basin). Int. J. Environ. Res. Public Health 2021, 18, 2775. [CrossRef] [PubMed]

27. Gellis, A.; Hereford, R.; Schumm, S.A.; Hayes, B.R. Channel evolution and hydrologic variations in the Colorado River basin: Factors influencing sediment and salt loads. J. Hydrol. 1991, 124, 317-344. [CrossRef]

28. Zhao, G.J.; Kondolf, G.M.; Mu, X. Sediment yield reduction associated with land use changes and check dams in a catchment of the Loess Plateau, China. Catena 2016, 148, 1-17. [CrossRef]

29. Huang, L.; Li, X.; Fang, H.; Yin, D.; Si, Y.; Wei, J. Balancing social, economic and ecological benefits of reservoir operation during the flood season: A case study of the Three Gorges Project, China. J. Hydrol. 2019, 572, 422-434. [CrossRef]

30. Jin, Z.; Cui, B.; Song, Y.; Shi, W.; Wang, K.; Wang, Y. How many check dams do we need to build on the Loess Plateau. Environ. Sci. Technol. 2012, 46, 8527-8528. [CrossRef] [PubMed]

31. Zhou, H.; Van Rompaey, A.; Wang, J.A. Detecting the impact of the "Grain for Green" program on the mean annual vegetation cover in the Shaanxi province, China using SPOT-VGT NDVI data. Land Use Policy 2009, 26, 954-960. [CrossRef] 
32. Du, J.; Shi, C.X.; Fan, X.L.; Zhou, Y.Y. Impacts of socio-economic factors on sediment yield in the Upper Yangtze River. J. Geogr. Sci. 2011, 21, 359-371. [CrossRef]

33. Bi, Z.L.; Zhang, Y.; Shi, P.; Zhang, X.; Shan, Z.X.; Ren, L.J. The impact of land use and socio-economic factors on ammonia nitrogen pollution in Weihe River watershed, China. Environ. Sci. Pollut. R. 2021, 28, 17659-17674. [CrossRef] [PubMed]

34. Whitehead, P.G.; Jin, L.; Macadam, I.; Janes, T.; Sarkar, S.; Rodda, H.J.E.; Sinha, R.; Nicholls, R.J. Modelling impacts of climate change and socio-economic change on the Ganga, Brahmaputra, Meghna, Hooghly and Mahanadi river systems in India and Bangladesh. Sci. Total Environ. 2018, 636, 1362-1372. [CrossRef] [PubMed] 